\title{
Romatoid Artritli Kadın Hastalarda Beslenme Durumunun Değerlendirilmesi
}

\author{
Nutritional Assessment of Female Patients with Rheumatoid Arthritis
}

\author{
Hülya Oğur'1, Rezzan Günaydın², Neslişah Rakıcığlu³
}

Geliş tarihi/Received: 27.06.2019 • Kabul tarihi/Accepted: 27.12.2019

\section{ÖZET}

Amaç: Bu çalışmanın amacı; romatoid artritli (RA) kadın hastaların beslenme durumunun saptanması ve fonksiyonel durum ile kas gücü arasındaki ilişkilerin incelenmesidir.

Bireyler ve Yöntem: Çalışma Romatoloji Polikliniği’ne kontrol amaçlı gelen, en az bir sene önce RA tanısı konmuş ve 10 mg'dan az metilprednizolon kullanımı olan 35-64 yaş arası kadın bireyler üzerinde gerçekleştirilmiştir. Çalışmaya katılmayı kabul eden hastaların beslenme durumu ve beslenme alışkanlıkları değerlendirilmiştir. Antropometrik ölçümler alınmış, bir günü hafta sonuna gelecek şekilde birbirini izleyen 3 günde bireysel besin tüketimi kaydedilmiş ve 24 saatlik fiziksel aktivite kayıtları sorgulanmıştır. Rutinde biyokimyasal parametrelere hasta dosyalarından ulaşılmıştır.

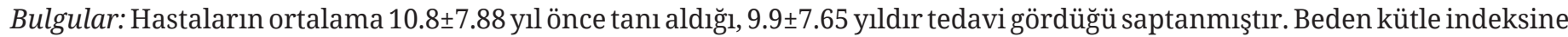
(BKİ) göre hastaların \% 9.9’u normal vücut ağırlığına sahipken, \%46.5’i hafif şişman, \%36.6’sı birinci derece obez, \%7’si ise ikinci derece obezdir. Hastaların \%88.7'sinin bel çevresi değeri $\geq 88 \mathrm{~cm}$; \%74.6’sının bel/kalça oranı 0.85’in üzerindedir. Bireylerin diyetle antioksidan alımlarına göre; $C$ vitamini ile hemoglobin ve albümin seviyeleri, $\beta$-karoten ile karaciğer fonksiyon testleri, toplam kolesterol ve Serum-Reaktif Protein (CRP) arasında pozitif ilişki saptanmıştır (p<0.05). Çoklu doymamış yağ asidi alımı ve alkalen fosfataz (ALP) değerleri arasında ise negatif ilişki bulunduğu gözlenmiştir (p<0.05). Hastaların diyetle günlük ortalama enerji, karbonhidrat, potasyum, kalsiyum ve demir alımlarının gereksinmenin altında olduğu saptanmıştır.

Sonuç: RA'in tedavisinde, semptomların azaltılması ve yaşam kalitesinin arttırılmasında hastaların tanı sonrasında diyetisyene yönlendirilerek beslenmeye ilişkin bilgi düzeyleri arttırılmalıdır. Yine bu hastalarda değerlendirme yapılırken BKİ’nin yanı sıra vücut yağ yüzdesi ve kas gücü gibi yöntemlerin de kullanılması gerektiği sonucuna varılmıştır.

Anahtar kelimeler: Romatoid artrit, besin ögesi alımı, beslenme durumu, antropometrik ölçümler, el kavrama gücü

\section{ABSTRACT}

Aim: The aim of this study was to determine the nutritional status of female patients with rheumatoid arthritis (RA) and to investigate the relationship between functional status and muscle strength.

1. Sağlık Bilimleri Üniversitesi, İstanbul Bakırköy Prof. Dr. Mazhar Osman Ruh Sağlığı ve Sinir Hastalıkları Eğitim ve Araştırma Hastanesi, Beslenme ve Diyet Polikliniği, İstanbul, Türkiye

(1) https://orcid.org/0000-0002-1517-1895

2. Medical Park İzmir Hastanesi, Fizik Tedavi ve Rehabilitasyon Bölümü, 35575, Karşıyaka, İzmir, Türkiye

(1) https://orcid.org/0000-0001-6581-3174
3. İletişim/Correspondence: Hacettepe Üniversitesi Sağlık Bilimleri Fakültesi Beslenme ve Diyetetik Bölümü, Ankara, Türkiye E-posta: neslisah@hacettepe.edu.tr • $\odot$ https://orcid.org/0000-0001-8763-7407 
Subjects and Methods: This study was performed on 35-64 years old female patients applied to the Rheumatology Outpatient Clinic for control purposes and diagnosed with RA at least one year ago and using methylprednisolone less than $10 \mathrm{mg}$. Nutritional status and feeding habits of the patients accepted to participate in the study were evaluated. Anthropometric measurements were taken, dietary intakes were recorded for 3 consecutive days including one weekend day, and 24-hour physical activity records were questioned. The routine biochemical parameters were taken from the patient files.

Results: Patients were diagnosed for $10.8 \pm 7.88$ years ago and treated for $9.9 \pm 7.65$ years. According to body mass index (BMI), 9.9\% of the patients had normal body weight, $46.5 \%$ were overweight, $36.6 \%$ were first degree obese and $7 \%$ were second degree obese. The percentages of patients with waist circumference $\geq 88 \mathrm{~cm}$ were found $88.7 \%$. Also, $84.5 \%$ of the patients had waist/hip ratio above 0.85 . A positive correlation was found between vitamin C, hemoglobin and albumin levels, also between $\beta$-carotene and liver function tests, total cholesterol and C-Reactive Protein (CRP) ( $<<0.05)$, according to dietary antioxidant intake. There was a negative correlation between polyunsaturated fatty acid intake and alkaline phosphatase (ALP) values ( $<$ 0.05). The mean daily intake of energy, carbohydrate, potassium, calcium and iron were found to be below the requirements.

Conclusion: It was concluded that patients should be referred to a dietitian after $\mathrm{h}$ diagnosed for RA to reduce symptoms and improve quality of life. Also, while assessing the patients, methods such as body fat percentage and muscle strength should be used with BMI.

Keywords: Rheumatoid arthritis, nutrients intake, nutritional status, anthropometric measurements, handgrip strength

\section{GİRIŞ}

Romatoid artrit (RA), protein enerji metabolizmasinda sitokin duyarlıklı tahrifata yol açan, kas kütlesinin azalmasına, vücut ağırlık kaybı ve anoreksiyaya sebep olan ekstra artiküler özellikleri olan sistemik bir hastalıktır (1). RA'da kronik inflamasyon, metabolik indeksin ve nutrisyonel gereksinmelerin artmasına neden olmakta ve besin alımını azaltmaktadır. Bunun yanında, yiyecekleri satın alma ve pişirmedeki fiziksel zorluklar, alt çene eklemine bağlı sjögren sendromunda görülen çiğneme ve yutma güçlüğü, sekonder ilaç tedavisine bağlı gelişen mide bulantısı ve iştahsızlık RA hastalarının beslenme durumunu olumsuz etkilemektedir. Kronik hastalıkların beslenme durumunda yetersizliklere yol açabildiği ve bu durumun vital ve fonksiyonel durumda kötüleşme ile ilişkilendirildiğini belirten bir çalışmada, kronik inflamatuvar hastalık olan RA'nın da yetersiz beslenme ile ilişkili hastalıklar listesine dâhil edilmeye aday olduğu belirtilmiştir (2). Bunun yanında RA hastalarının hastalık öncesi aynı ağırlıkta kalmalarına rağmen, yaklaşık üçte ikisinin istemsiz olarak yağsız kas kütlesinde kayıp ve ilerleyen süreçte vücut yağ kütlesinde artış yaşadığı belirtilmiştir. $\mathrm{Bu}$ durum romatoid kaşektik obezite olarak tanımlanmıştır (3,4). RA'da istemsiz yağsız kas kütlesindeki kaybın kanser ya da Edinilmiş Bağışıklık Yetersizliği Sendromu (AİDS)'na bağlı kaşeksi gibi mortalitede direk etkili olmamasına rağmen kas gücü ve fonksiyonel kapasiteyi olumsuz etkileyerek komorbiditeye ve yaşam kalitesinde azalmaya yol açabilmektedir (4).

$\mathrm{Bu}$ çalışmanın amacı; RA'lı hastaların besin tüketim durumlarının saptanması, besin ögesi yetersizliklerinin belirlenmesi ve fonksiyonel durum ile kas gücü arasındaki ilişkinin incelenmesidir.

\section{BİREYLER VE YÖNTEM}

Bu çalışma; Mart 2011-Mart 2012 tarihleri arasında İzmir Bozyaka Eğitim Araştırma Hastanesi Fizik Tedavi Bölümü Romatoloji Polikliniği’ne kontrol amaçlı gelen, en az bir sene önce RA tanısı konmuş ve 10 mg’dan az metilprednizolon kullanımı olan, 35-64 yaş arası gönüllü bireyler üzerinde gerçekleştirilmiştir. Çalışmaya katılacak hasta sayısı, ilgili poliklinikte takipli RA tanılı (araştırma kriterlerini gözetmeksizin) 
134 hasta üzerinden gerekli istatiksel hesaplamalar yapıldıktan sonra \%95 güven aralığı ile 68 hasta olarak belirlenmiştir. Çalışma için, Hacettepe Üniversitesi Klinik Araştırmalar Senato Etik Komisyonu tarafindan 410.01-591 sayı ve 25 Şubat 2011 tarihli "Etik Komisyonu Onayı" alınmıştır.

Çalışmaya katılmayı kabul eden hastalara uygulanan anket formu; kişisel ve hastalığa ait bilgiler, beslenme durumu ve beslenme alışkanlıkları ile antropometrik ölçümler, besin tüketimi kayıtları, fiziksel aktivite kayıtları hakkında açık ve kapalı uçlu sorulardan oluşmaktadır.

Bir günü hafta sonuna gelecek şekilde birbirini takip eden üç günde, "bireysel besin tüketim kaydı” ve bir günlük "bireysel fiziksel aktivite kaydı" alınmıştır. Bireysel besin tüketim kayıtları için hastalardan belirtilen günlerde yediklerini kaydetmeleri istenmiş ve kayıtlar tamamlandıktan bir gün sonra araştırmacı diyetisyen tarafından kayıtlar sorgulanarak detaylandırılmış ve teyit edilmiştir. Diyetle alınan günlük ortalama enerji ve besin ögesi değerleri Beslenme Bilgi Sistemi Programı (BEBİs 7.0) kullanılarak araştırmacı tarafından hesaplanmıştır (5). Bulunan değerler yaş ve fizyolojik duruma göre Önerilen Günlük Alım Miktarı (Recommended Dietary Allowances, RDA) ile klyaslanmıştır (6). Enerji ve besin ögelerinin gereksinmenin >\%67'sini karşılama durumu "yeterli" olarak kabul edilmiştir (7).

Fiziksel aktivite durumunun saptanmasında, geriye dönük 24 saatlik fiziksel aktivite kaydı formu kullanılmıştır. Aktiviteler için harcanan süre, dakikadaki bazal metabolizma hızı (BMH) için belirlenen fiziksel aktivite katsayısı (PAR) ile çarpılarak toplam enerji harcaması (TEH) hesaplanmıştır. TEH, BMH'na bölünerek fiziksel aktivite düzeyi (PAL) bulunmuş ve Dünya Sağllk Örgütü (DSÖ)’nün sınıflamasına göre değerlendirilmiştir (7).

Hastaların fonksiyonel durumları, ülkemizde güvenilirlik ve geçerlilik çalışması yapılmış olan Sağlık Değerlendirme Anketi (SDA) ile yapılmıştır (8). SDA skorları 0-3 arasında değişmekte olup, 3 puan ciddi fonksiyonel yetersizliğini göstermektedir (9).
Hastaların vücut ağırlığı, boy uzunluğu, bel, kalça ve üst orta kol çevresi ölçümleri alınmış, el kavrama gücü ölçümleri kaydedilmiştir. Bireylerin vücut ağırlıkları ve kompozisyonları $150 \mathrm{~kg}$ ağırlığa dayanıklı 0.1 kg'a duyarlı Innerscan BC 532 Tanita cihazı ile ölçülmüştür. Boy uzunluğu, bel, kalça ve üst orta kol çevresi esnemeyen mezür ile yöntemine uygun ölçülmüştür. Vücut ağırlığı ve boy uzunluğu ile elde edilen verilerden faydalanılarak BKİ değeri hesaplanmış ve DSÖ standartlarına uygun olarak BKİ $\leq 18.5 \mathrm{~kg} / \mathrm{m}^{2}$ zaylf; $18.5-24.9 \mathrm{~kg} / \mathrm{m}^{2}$ normal; 25.0 $29.9 \mathrm{~kg} / \mathrm{m}^{2}$ hafif şişman; 30.0-34.9 kg/m² I. derece şişman, $35.0-39.9 \mathrm{~kg} / \mathrm{m}^{2}$ II. derece şişman, $\geq 40 \mathrm{~kg} /$ $\mathrm{m}^{2}$ III. derece şişman olarak değerlendirilmiştir. Bel çevresi için kadınlarda $<80 \mathrm{~cm}$ normal, $\geq 88 \mathrm{~cm}$ ise risk olarak değerlendirilmiştir. Bel/kalça oranı kadınlarda $\geq 0.85$, risk olarak değerlendirilmiştir (7).

El kavrama gücü (EKG), Grip D T.K.K. 5401 marka el dinamometresi kullanılarak ölçülmüştür. Ölçümler, bireyler ayakta, dirsek ve el bileği tam ekstansiyonda iken yapılmıştır. Baskın ve baskın olmayan ellerin, beş saniye ara ile ölçümleri ikişer kez tekrarlanarak, ortalamaları alınmış ve değerler kilogram cinsinden kaydedilmiştir (7).

İzmir Bozyaka Eğitim ve Araştırma Hastanesi Biyokimya Laboratuvarı'nda hastalar için rutinde yapılan biyokimyasal analizlerin (açlık glukozu, toplam kolesterol, yüksek dansiteli lipoprotein [HDL], düşük dansiteli lipoprotein [LDL], trigliserid, ürik asit, aspartat aminotransferaz [AST], alkalen fosfataz [ALP], alanin aminotransferaz [ALT]. kreatinin, üre, sodyum, potasyum, kalsiyum, total protein, albumin, serum reaktif protein [CRP], hemoglobin, hematokrit, $\mathrm{B}_{12}$ vitamini), sonuçları son kontrollerinde hasta dosyalarından kaydedilmiştir.

\section{Verilerin İstatistiksel Değerlendirmesi}

Verilerin istatistiksel değerlendirilmesinde, SPSS 15.0 bilgisayar programı kullanılmıştır. Çalışmada tanımlayıcı istatistiklerden verilerin özelliğine göre dağılım tabloları veya aritmetik ortalama $(\overline{\mathrm{X}})$, standart sapma (SS) değerleri ile en düşük-yüksek (alt- 
üst) aralıkları kullanılmıştır. Değişkenler arasındaki ilişkinin belirlenmesinde Pearson Korelasyon Testi uygulanmıştır. Tüm analizlerde $\mathrm{p}<0.05$ olması istatiksel olarak önemli kabul edilmiştir (10).

\section{BULGULAR}

Çalışmada 5 erkek, 71 kadın hastaya ulaşılmıştır. Erkek örneklemin yetersizliğinden ötürü yaş ortalaması $51.8 \pm 7.43$ yll olan 71 kadın hasta değerlendirmeye alınmıştır. Hastalar 10.8 \pm 7.88 yıl önce RA tanısı almış

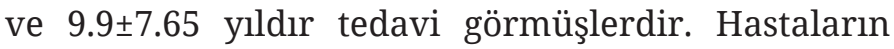
\%59.0'ının RA dışında doktor tarafindan tanısı konmuş kronik hastalığı olduğu saptanmıştır. $\mathrm{Bu}$ hastalıkların başında hipertansiyon (\%42.4), anemi (\%40.7), ülser/gastrit (\%23.7), obezite ve kalp damar hastalıkları (\%16.9) geldiği gözlenmiştir. RA’ya yönelik ilaç tedavilerinden en sık hastalığı modifiye eden antiromatizmal ilaçlar (DMARD) ile kortikosteroid tedavisinin kombinasyonu (\%33.8) ve tek başına DMARD (\%28.2) kullanılmıştır. RA'ya yönelik ilaç tedavisi dışında hastaların \%41.0’ı diğer hastalıklarına yönelik ilaç tedavisi almış ve en sık antihipertansifler (\%36.6) ve peptik ülser/gastro-özofageal reflü ilaçları (\%58.5) kullanılmıştır.

Hastaların SDA skoru ortalaması $1.3 \pm 0.74$ olarak bulunmuştur (Tablo 1). Bireylerin \%59.2'sinin günlük işlerde yardım aldıkları ve en çok yardım alınan günlük aktivitelerin sırasıyla; alışveriş, bahçe ve ev işleri gibi günlük işler (\%76.2) ve elle kavrama (\%54.8) olduğu belirlenmiştir (Tabloda gösterilmemiştir).

Hastaların \%47.9'unun hastalıklarına ilişkin doktor (\%70.6) ya da diyetisyenden (\%29.4) diyet önerisi aldıkları saptanmış, \%50.7'si ise her hangi bir diyet önerisi alarak ya da almayarak diyet uyguladıklarını ifade etmişlerdir. Tuzsuz diyetin en sık uygulanan diyet olduğu belirtilmiştir (\%86.1). Hastaların \%47.9'u tanı aldıktan sonra besin tüketimlerinde değişiklik yaptıklarını ifade etmişlerdir (Tabloda gösterilmemiştir).
Tablo 1'de hastaların SDA skorları, antropometrik ölçümleri, toplam enerji harcaması ve fiziksel aktivite düzeylerine ilişkin verileri yer almaktadır. Hastaların BKİ ortalaması $30.4 \pm 5.51 \mathrm{~kg} / \mathrm{m}^{2}$ dir. Bel ve kalça çevresi ortalamaları ise sırasıyla $100.1 \pm 12.36$ $\mathrm{cm}, 111.8 \pm 11.82 \mathrm{~cm}$ olarak saptanmıştır. Vücut yağ yüzdesi ortalamaları ise $38.8 \pm 8.77$ 'dir (Tablo 1). BKİ sınıflamasına göre hastaların \%9.9’u normal ağırlığa sahipken, \%46.5’i hafif şişman, \%36.6’sı birinci derece obez, \%7.0'si ise ikinci derece obezdir. Bel çevresi ölçümleri değerlendirildiğinde; \%2.8’i $80 \mathrm{~cm}$ altında, \%8.5'inin 80-88 cm arasında, \%88.7'si $88 \mathrm{~cm}$ ve üzerindedir. Hastaların \%74.6'sının bel/kalça oranı 0.85 ve üzeriyken, $\% 25.4$ 'ü 0.85 'in altındadır (Tabloda gösterilmemiştir).

Hastaların EKG ortalamaları 16.1 \pm 6.24 olarak bulunmuştur (Tablo 1). Vücut ağırlığı normal olan hastaların ortalama EKG'leri $17.4 \pm 6.77 \mathrm{~kg}$, hafif şişman bireylerin $16.7 \pm 6.96 \mathrm{~kg}$, birinci derece obez bireylerin $15 \pm 5.08 \mathrm{~kg}$ ve ikinci derece obez bireylerin $16.7 \pm 6.85$ kg’dır (Tabloda gösterilmemiştir).

Tablo 1. Hastaların SDA skorları, antropometrik ölçümleri, toplam enerji harcaması ve fiziksel aktivite durumuna ilişkin veriler

\begin{tabular}{lcc}
\hline Ölçümler & $\overline{\mathrm{X}}_{ \pm \text {SS }}$ & Alt-Üst \\
\hline Vücut ağırlı̆̆ı (kg) & $76.6 \pm 14.07$ & $45.8-125.5$ \\
Boy uzunluğu (m) & $1.6 \pm 0.06$ & $1.4-1.74$ \\
BKİ $\left(\mathrm{kg} / \mathrm{m}^{2}\right)$ & $30.4 \pm 5.51$ & $20.9-52.2$ \\
Üst orta kol çevresi (cm) & $33.2 \pm 3.93$ & $22.0-43.0$ \\
Kalça çevresi (cm) & $111.8 \pm 11.82$ & $88.0-157.0$ \\
Bel çevresi (cm) & $100.1 \pm 12.36$ & $71.0-142.0$ \\
Yağsız vücut kütlesi (kg) & $44.7 \pm 8.3$ & $32.0-90.0$ \\
Vücut yağ yüzdesi (\%) & $38.8 \pm 8.77$ & $22.2-84.0$ \\
EKG (kg) & $16.1 \pm 6.24$ & $3.2-36.5$ \\
SDA skoru & $1.3 \pm 0.74$ & $0-2.6$ \\
TEH (kkal) & $2398.5 \pm 385.38$ & $1709.3-2687.0$ \\
BMH (kkal) & $1419.9 \pm 192.74$ & $1032.0-2012.0$ \\
PAL & $1.7 \pm 0.15$ & $1.1-2.1$ \\
\hline BKi்: Beden kütle indeksi, EKG: El kavrama gücü, SDA: Sağlk değerlendirme \\
anketi, TEH: Toplam enerji harcaması, BMH: Bazal metabolizma hizı, PAL: \\
Fiziksel aktivite düzeyi \\
${ }^{*}$ Yüzde
\end{tabular}


Tablo 2. Hastaların biyokimyasal bulguları

\begin{tabular}{lccc}
\hline Biyokimyasal bulgular & $\overline{\mathrm{X}}_{ \pm}$SS & Alt-Üst & Referans aralık \\
\hline Açlik glukozu (mg/dL) & $91.9 \pm 14.12$ & $67.0-138.0$ & $70.0-110.0$ \\
Toplam kolesterol (mg/dL) & $207.3 \pm 33.18$ & $156.0-306.4$ & $40.0-200.0$ \\
LDL (mg/dL) & $137.0 \pm 41.71$ & $79.0-278.0$ & $0.0-110.0$ \\
HDL (mg/dL) & $59.3 \pm 17.67$ & $31.0-109.0$ & $45.0-100.0$ \\
Trigliserid (mg/dL) & $123.1 \pm 61.40$ & $27.0-277.0$ & $40.0-150.0$ \\
Ürik asit (mg/dL) & $4.4 \pm 1.48$ & $2.0-10.8$ & $2.6-6.0$ \\
AST (U/L) & $19.4 \pm 7.70$ & $9.0-56.0$ & $5.0-37.0$ \\
ALP (U/L) & $78.6 \pm 27.49$ & $27.0-175.0$ & $21.0-447.0$ \\
ALT (U/L) & $21.9 \pm 10.25$ & $6.0-63.0$ & $0.0-33.0$ \\
Kreatinin (mg/dL) & $0.7 \pm 0.18$ & $0.5-1.7$ & $0.5-0.9$ \\
Üre (mg/dL) & $30.5 \pm 11.53$ & $14.0-78.0$ & $10.0-50.0$ \\
Sodyum (mmol/L) & $140.2 \pm 3.07$ & $130.0-148.0$ & $137.0-146.0$ \\
Total protein (g/dL) & $7.1 \pm 0.59$ & $4.7-8.1$ & $6.6-8.8$ \\
Albümin (g/dL) & $4.2 \pm 0.39$ & $2.7-5.3$ & $3.5-5.5$ \\
CRP (mg/dL) & $1.4 \pm 4.61$ & $0.1-38.1$ & $0.0-0.34$ \\
Potasyum (mmol/L) & $4.5 \pm 0.50$ & $3.1-5.8$ & $3.5-5.2$ \\
Kalsiyum (mg/dL) & $7.0-10.6$ & $8.1-10.7$ \\
Hematokrit (\%) & $9.3 \pm 0.57$ & $28.1-46.2$ & $39.5-50.3$ \\
Hemoglobin (g/dL) & $37.0 \pm 4.22$ & $8.8-16.0$ & $13.6-17.2$ \\
B 12 vitamini (pg/mL) & $12.6 \pm 1.60$ & $97-650$ & $126.5-505.1$ \\
\hline ALP: Alkalen fosfataz, ALT: Alanin aminotransferaz, AST: Aspartat aminotransferaz, CRP: Serum reaktif protein, HDL: Yüksek dansiteli lipoprotein, LDL: Düşük \\
dansiteli lipoprotein, & & &
\end{tabular}

Hastalara ilişkin biyokimyasal bulgular Tablo 2'de verilmiştir. Hastaların ortalama toplam kolesterol, LDL-kolesterolü ve CRP değerleri referans aralığın üzerinde bulunmuştur (Tablo 2).

Tablo 3. Bireylerin hastalık süresi, antropometrik ölçümleri, SDA skoru, enerji harcamaları ile EKG arasındaki ilişki

\begin{tabular}{lcc}
\hline \multirow{2}{*}{ Değişkenler } & \multicolumn{2}{c}{ EKG } \\
\cline { 2 - 3 } & $\mathbf{r}$ & $\mathbf{p}$ \\
\hline Hastalık süresi (yll) & -0.207 & 0.830 \\
Vücut ağırlığı (kg) & 0.115 & 0.339 \\
BKİ (kg/m²) & -0.018 & 0.880 \\
Üst orta kol çevresi (cm) & 0.276 & $0.020^{*}$ \\
Yağsız vücut kütlesi (kg) & -0.004 & 0.974 \\
Vücut yağ yüzdesi (\%) & 0.013 & 0.913 \\
BMH (kkal) & 0.173 & 0.149 \\
SDA skoru & -0.493 & $0.000^{*}$ \\
TEH (kkal) & 0.314 & $0.008^{*}$ \\
PAL & 0.273 & $0.021^{*}$ \\
\hline BKi்: Beden kütle indeksi, BMH: Bazal metabolizma hizl, EKG: El kavrama \\
gücü, PAL: Fiziksel aktivite düzeyi, SDA: Sağlik değerlendirme anketi, TEH: \\
Toplam enerji harcaması, ${ }^{*}$ p<0.05 & \multicolumn{2}{l}{}
\end{tabular}

Hastaların hastalık süresi, antropometrik ölçümleri, SDA skoru, enerji harcamaları ile EKG arasındaki ilişki Tablo 3’te gösterilmiştir. Hastaların üst orta kol çevresi (cm) ( $r=0.276, \mathrm{p}=0.020)$, TEH (kkal) ( $\mathrm{r}=0.314$, $\mathrm{p}=0.008)$ ve PAL değerleri $(\mathrm{r}=0.273, \mathrm{p}=0.021)$, EKG ile pozitif ilişkili, SDA skoru ise EKG ile negatif ilişkili ( $\mathrm{r}=-$ 0.493, $\mathrm{p}=0.000)$ bulunmuştur $(\mathrm{p}<0.05)$.

Tablo 4'te hastaların diyetle günlük enerji ve besin ögelerini alım düzeyleri ve gereksinmeyi karşılama yüzdeleri verilmiştir. Hastaların diyetle günlük ortalama enerji, karbonhidrat, potasyum, kalsiyum ve demir alımlarının, gereksinmenin altında olduğu saptanmıştır (Tablo 4).

Hastaların besin gruplarındaki besinleri tüketim miktarları değerlendirildiğinde; süt ve ürünleri, etleri (kırmızı et, tavuk, balık vb.), sebze ve meyveleri günlük önerilen miktarların altında tükettikleri saptanmıştır (Tabloda gösterilmemiştir). 
Tablo 4. Bireylerin diyetle günlük enerji ve besin ögesi alım düzeyleri ile gereksinmeyi karşllama yüzdeleri

\begin{tabular}{|c|c|c|c|}
\hline Enerji ve besin ögesi & $\overline{\mathrm{X}} \pm \mathrm{SS}$ & Alt-Üst & RDA \% \\
\hline Enerji (kkal) & $1418.8 \pm 449.6$ & $661.3-2940.9$ & 59.0 \\
\hline Protein (g) & $57.8 \pm 23.7$ & 21.9-125.1 & 120.0 \\
\hline Protein (\% enerji) & 16.9 & $11-35$ & \\
\hline Yağ (g) & $53 \pm 24.9$ & $13.9-157.8$ & 67.0 \\
\hline Yağ (\% enerji) & 32.6 & $16-50$ & \\
\hline Doymuş yağ asidi (g) & $21 \pm 10.7$ & $3.9-50.7$ & \\
\hline Tekli doymamış yağ asidi (g) & $1.1 \pm 0.4$ & $0.41-2.51$ & \\
\hline Çoklu doymamış yağ asidi (g) & $27.2 \pm 10.3$ & $7.62-65.3$ & \\
\hline Kolesterol (mg) & $206.9 \pm 136.4$ & $12.25-637$ & \\
\hline Karbonhidrat (g) & $172.7 \pm 60.8$ & $85.2-401.4$ & 49.0 \\
\hline Karbonhidrat (\% enerji) & 50.5 & $32-71$ & \\
\hline Posa (g) & $20.2 \pm 8.2$ & $6-45.8$ & 67.0 \\
\hline Suda çözünen posa (g) & $6.3 \pm 3.2$ & $1.6-21.4$ & \\
\hline Suda çözünmeyen posa (g) & $12.5 \pm 5.5$ & 3.8-33.4 & \\
\hline A vitamini $(\mu g)$ & $1080.8 \pm 763.5$ & 168.9-3973.4 & 135.0 \\
\hline E vitamini (mg) & $8 \pm 7.5$ & $1.2-55.2$ & 80.0 \\
\hline $\mathrm{B}_{1}$ vitamini (mg) & $0.7 \pm 0.2$ & $0.3-1.5$ & 67.0 \\
\hline $\mathrm{B}_{2}$ vitamini (mg) & $1.1 \pm 0.4$ & $0.3-2.6$ & 94.0 \\
\hline $\mathrm{B}_{6}$ vitamini (mg) & $1.1 \pm 0.4$ & $0.4-2.5$ & 89.0 \\
\hline $\mathrm{B}_{12}$ vitamini $(\mu \mathrm{g})$ & $1.9 \pm 1.7$ & $0-9.2$ & 64.0 \\
\hline C vitamini (mg) & $116.7 \pm 94.2$ & $7.8-326.8$ & 117.0 \\
\hline Sodyum (mg)* & $2536.4 \pm 1292$ & $918.1-8181.2$ & 127.0 \\
\hline Potasyum (mg) & $1920.6 \pm 737.2$ & $597-4074$ & 55.0 \\
\hline Kalsiyum (mg) & $627.1 \pm 280.3$ & $168-1744.4$ & 63.0 \\
\hline Magnezyum (mg) & $216.1 \pm 100.4$ & $68.7-704.7$ & 70.0 \\
\hline Demir (mg) & $9.7 \pm 3.4$ & $4-19.5$ & 64.0 \\
\hline Çinko (mg) & $7.5 \pm 2.7$ & $3.24-14.5$ & 107.0 \\
\hline Bakır (mg) & $1.3 \pm 0.5$ & $0.6-2.7$ & 104.0 \\
\hline
\end{tabular}

*Yemeklere eklenen tuzdan gelen sodyum hesaplamaya katılmamıştır. RDA: Önerilen Günlük Alım Miktarı (Recommended Dietary Allowances)

Hastaların diyetle besin ögesi alımları ile biyokimyasal bulguları arasındaki ilişki değerlendirildiğinde; C vitamini ile hemoglobin ve albümin seviyeleri; $\beta$-karoten ile karaciğer fonksiyon testleri (ALT ve AST), toplam kolesterol ve CRP arasında pozitif ilişki gözlenmiştir $(\mathrm{p}<0.05)$. Çoklu doymamış yağ asidi tüketimi ve ALP değerleri arasında ise negatif ilişki bulunmuştur $(\mathrm{p}<0.05)$ (Tabloda gösterilmemiştir).

\section{TARTIŞMA}

Bireylerin beslenme durumunu; kayıpları telafi etmek, depoları korumak ve fizyolojik faaliyetlerin devamlılığını sağlamak için diyetle alınan besin ögeleri ile gereksinmeler arasindaki denge belirlemektedir (2). Bu çalışma, RA hastalarında beslenme durumunun saptanması ve fonksiyonel durum ile kas gücü arasındaki ilişkilerin incelenmesi amacıyla gerçekleştirilmiştir.

Klinikte vücut yağı ve kardiyovasküler risk başta olmak üzere sağlık risklerinin belirlenmesinde genel popülasyon üzerinde sık kullanılan bir yöntem olan BKİnin kullanılmasinın, RA hastalarında yetersiz olduğu belirtilmiştir (3). Sağlıklı kontrollerle karşılaştırıldığında, RA hastalarının vücut yağ 
yüzdelerindeki beklenen artıştan dolayı, BKİnin hafif şişman ve şişman sınıflamasının kesim noktalarının 2 $\mathrm{kg} / \mathrm{m}^{2}$ düşürülmesi gerektiği sonucuna varılmış, vücut ağırlığından bağımsız olarak abdominal yağlanmanın değerlendirilmesi gerektiği ve bu hastalarda vücut yağ kütlesindeki artışı, hastalık aktivitesi ile pozitif ilişskili olduğu belirtilmiştir $(3,11)$.

Kas gücünün değerlendirilmesinde kullanilan biyofizik yöntemlerden EKG'nin azalması, eklem ağrılarından ve bozulmuş hastalık aktivitesinden dolayı RA hastalarında sık görülmektedir $(12,13)$. Bu çalışmada, SDA skorlarının yüksekliği hastalık aktivitesini/fonksiyonel kapasitelerini yansıtan bir belirteç olarak kullanılmış ve EKG ile negatif ilişki göstermiştir. Bu durum, RA hastalarının kas güçleri ve fonksiyonel kapasitelerinin pozitif ilişkili olduğunu gösteren çalışmalar ile paralellik göstermektedir $(14,15)$.

Bu çalışmada BKİne göre hastaların \%9.9'u normal ağırlığa sahipken, \%2.8'inde bel çevresi ölçümü $<80$ $\mathrm{cm}$ bulunmuştur. Normal BKI'ne sahip olanların EKG ortalamaları yüksek görünse de EKG ölçümleri BKİ grupları arasında istatistiksel olarak farklı bulunmamıştır. Çalışmanın sonuçları, Walsmith ve Roubenhoff'un (4) tanımlamasina uygun olup hastalık aktivitesi arttıkça kas kütlesi azalmakta, yağ kütlesi artmaktadır. Bu nedenle hastaların vücut kompozisyonlarını değerlendirmede, BKİ değerinin yetersiz kaldıği; EKG, üst orta kol çevresi, bel çevresi ve bel kalça oranı gibi daha spesifik yöntemlerin de değerlendirilmesi gerektiği sonucuna varılmıştır.

Bu çalışmanın sonuçları, EKG ile TEH (kkal/gün) ve PAL değerlerinin pozitif ilişkili olduğunu gösterilmiştir (Tablo 3). Tümor nekroz faktör-a, RA gibi inflamatuvar hastalıkların patogenezinde rol oynamakta ve kas proteinlerinin yıkımı ile iskelet kası hücrelerinin anabolik uyarıcılara karşı duyarlılığının azalmasına yol açmaktadır. Aynı zamanda, eklemlerde ağrı ve fiziksel aktivitede azalmaya yol açarak kas gücü üzerinde etki göstermektedir. Bu durum, fiziksel aktivite yetersizliğinin temel sebeplerinden birinin, inflamatuvar yanit nedeniyle meydana gelen kas kaybından kaynaklandığının göstergesidir (16). RA'da iskelet kaslarındaki moleküler değişikliklerin hastaların aktivitesi ve engellilik durumunu ile ilişkisini bir çalışmada; moleküler kas analizlerinde, proinflamatuar süreçlerin engellilik ve kas kütlesi kaybına neden olabileceği ve TEH'da azalmaya yol açabileceği sonucuna varılmıştır (17).

RA hastalarında yeterli egzersizin kas kütlesinin artışında olumlu etkileri olduğu sonucuna varılmıştır. Özellikle yüksek duyarlıklı direnç egzersizlerinin romatoid kaşekside görülen kas kaybını gerilettiği ve engellilik düzeylerinde azalmaya yol açttğı belirtilmiştir $(16,18)$. Bu çalışmanın sonuçları, kas kütlesinin göstergesi olan EKG'nin PAL ile gerek sebep gerekse sonuç ilişkisi içinde olabileceğini, bu durumun hastaların aktivite için harcadıkları enerjiyi kısıtlayarak, TEH'da azalmaya yol açabileceğini göstermektedir.

Beslenme ile kardiyovasküler hastalıklar, kanser, diyabet gibi kronik hastalıklar arasında güçlü bir ilişki bulunmaktadır ve bu hastalıklara ait kanıta dayalı beslenme rehberleri oluşturulmuştur. Ancak RA gibi inflamatuvar hastalıklara yönelik kesin kanıta dayalı beslenme rehberleri bulunmamakta ve pek çok hasta beslenme ile ilgili hekimine danışma ihtiyacı hissetmektedir (19). Bu hasta grubuna verilecek pratik beslenme önerilerinin hastalığın ilerlemesinde ve remisyon durumunun devam ettirilmesine katkıda bulunacağı düşünülmektedir (20). RA hastalarını, \%33-75'i yiyeceklerin hastalıklarında önemli olduğunu düşünürken, sadece \%20-50'sinin diyetlerinde değişiklik yaptığı belirtilmiştir (21). $\mathrm{Bu}$ çalışmada, en çok uygulanan diyet türü tuzsuz diyettir. Hastaların diyetisyenle görüşmedikleri halde hastalık sonrası diyette değişiklik yapma eğiliminde olduğu gösterilmiştir. RA'nın özellikle erken evrelerinde kullanılmaya başlanan yüksek doz kortikosteroidler, hiperglisemi, obezite, gastrik ülserasyon ve böbreklerden tuzun geri emilimini artırması nedeniyle, ödem oluşumu ve hipertansiyon gibi yan etkilere sebep olabileceği belirtilmiştir (22). $\mathrm{Bu}$ çalışmada da, diğer bir çalışma sonucunu destekler nitelikte, diyetisyenin multidisipliner ekip protokolü 
içinde yer almasının hastaların diyetleri ile ilgili bilgi eksiklerinin giderilmesine ve yaşam kalitelerine fayda sağlayacağı düşünülmektedir (23).

$\mathrm{Bu}$ çalışmada besin tüketim kayıtlarından elde edilen verilere göre günlük süt ve ürünlerini, et ve sebze/ meyveleri tüketimlerinin, yetişkin bireylere önerilen miktarların altında olduğu gözlenmiştir. Nitekim, RA hastalarının besin tüketimlerinin önerilen düzeylerin altında olmasının yanı sıra diyet kalitelerinin de sıklıkla kötü olduğu bildirilmiştir(24).

Yapılan bir çalışmada, RA hastalarının, sağlıklı kontrollere göre enerji ve mikrobesin ögesi alımlarının yetersiz olduğuna değinilmiş, bu durumun hastalıktan kaynaklı ihtiyaç duyulan spesifik besin ögesi alımları ile ilişkili olduğu ifade edilmiştir. RA hastalarında besinlerle enerji alımının mutlaka gözlenmesi gereken bir kriter olduğu sonucuna varılmıştır (25). Diğer bir çalışmada, RA hastalarının kontrol grubuna göre daha yüksek enerji aldıkları ancak bunun nedeninin RA grubunda özellikle karbonhidrat ve doymuş yağ içeriği yüksek olan yiyecekler tüketmelerine bağlamıştır. Beslenme yetersizliğinin önüne geçilmesi ve özellikle enerji ve mikro besin ögelerinin dengeli alınması için hastaların diyetisyene yönlendirilmesi gerektiği vurgulanmıştır (2).

$\mathrm{Bu}$ çalışmada hastaların özellikle $\mathrm{B}_{12}$ vitamini, kalsiyum ve demir alımının önerilerin altında olduğu gözlenmiştir (Tablo 4). RA hastalarının bir yıl süre ile 3 ayda bir kez besin tüketimlerinin takip edildiği bir çalışmada, besinlerle $\mathrm{B}_{12}$ vitamini, kalsiyum ve demirin yetersiz alındığı belirtilmiştir. Özellikle kadın RA hastalarında üreme döneminde demir eksikliğinin önemine değinilmiş, uzun dönem RA için kullanılan ilaçların kalsiyum metabolizmasında bozulmalara yol açarak kemik hastalıklarına yatkınlığın artabileceğini belirtmişlerdir (26). Bu çalışmada da, diyetle alımları doğrultusunda RA hastalarının demir eksikliği anemisi, kemik erimesi ve deformasyonlarına karşın beslenme konusunda bilinçlendirilmeleri gerektiği sonucuna varılmıştır.

RA'lı hastalarda diyetle günlük enerji alımının \%5060'nın karbonhidratlardan, \%25-30’unun yağlardan (doymuş yağ asidi [DYA], tekli doymamış [TDYA], çoklu doymamış yağ asitleri [ÇDYA] oranı 0.5:1.5:1 olacak şekilde)sağlanması önerilmektedir (27). Bu çalışmada, makro besin ögesi dağılımları önerilere yakın dağılım göstermesine rağmen yağdan gelen enerjinin \%30’un üzerinde olması ve DYA:TDYA:ÇDYA oranının 1:1:0.5 olarak gözlenmesi, hastaların özellikle yağ tüketim miktar ve tercihleri konusunda bilinçlendirilmesi gerektiğinin göstergesidir.

Chiplonkar et al. (28) demir eksikliği anemisi ile mikro besin ögesi tüketim düzeyleri arasındaki ilişkiyi incelediği çalışmalarında, C vitamini alımı ve hemoglobin düzeylerinin pozitif ilişkili olduğunu, RA hastalarında sık görülen anemiden korunmak amaçlı diyetle C vitamini alımının arttırılmasını önermişlerdir. Bu çalışmada, $\mathrm{C}$ vitamini alımı ile hemoglobin düzeyi arasında pozitif ilişki bulunmuştur ve besinlerle alınan $\mathrm{C}$ vitamini düzeyi referans alım miktarının üzerindedir (Tablo 4). Ancak C vitaminin besin değeri kaybına karşı hassas bir vitamin olması nedeniyle, hastaların bu konuda bilinçlendirilmesi ve besin değeri kaybını minimuma indirgeyecek beslenme önerilerinin verilmesi gerektiği sonucuna varılmıştır.

ALP, RA hastalarında hastalı aktivitesinden etkilenen bir değerdir ve aktif dönemde artış gösterdiği belirtilmiştir (29). ÇDYA'dan özellikle n-3 suplementasyonun, RA hastalarında hastalık aktivitesine düşürdüğüne dikkat çekilmiştir (19). $\mathrm{Bu}$ çalışmada ALP değerinin yüksek olmamasına rağmen, ÇDYA ile negatif ilişkili olması, ÇDYA'nın hastalık aktivitesi üzerinde olumlu etki yaratacağının göstergesi olarak kabul edilmiştir.

RA gibi otoimmün hastalıkların özellikle ilerleyen dönemlerde kardiyovasküler riski arttırdığı belirtilmiştir. Sigara kullanımı, dislipidemi, yüksek BKİ, arteriyel hipertansiyon, tip 2 diabetes mellitus, düşük fiziksel aktivite ve hiperhomosisteinemi, RA'da kardiyovasküler risklerin belirlenmesinde kullanılan geleneksel faktörler olarak tanımlanmaktadır $(12,30)$. Bu çalışmaya katılan hastalar uzun dönem RA hastalarıdır (10.8 \pm 7.88 yll). Toplam kolesterol 
düzeyleri, BKİ değerleri, bel çevreleri ve bel kalça oranları referans değerlerin üzerindedir. Hastaların \%59.0’ı beslenme ile ilişkili olan ikincil bir hastalığa sahiptir ve sadece \%47.9'u hastalıklarına ilişkin beslenme önerisi aldıklarını belirtmişlerdir. Verilen beslenme önerilerinin çoğunun doktor tarafından verilmesi ve beslenme durumlarının düzenli takip edilmemesi hastaların yeterli beslenme bilgisine sahip olmadığının göstergesi olarak kabul edilmiş ve kardiyovasküler hastalıklar açısından risk altında oldukları sonucuna varılmıştır. Bu nedenle hastaların sadece hastalıklarına yönelik değil, beraberinde gelişebilecek ikincil hastalıklar ile ilgili de bilgilendirilmesi gerektiği ve beslenme danışmalığı almasının, hastaların yaşam kalitelerinin artışında etkili olacağı düşünülmektedir. Bu çalışmada, RA hastalarının hastalıktan ve tedavide kullanılan ilaçlardan kaynaklı beslenme durumlarının sürekli değerlendirilmesi gerektiği; değerlendirme yapılırken BKİnin yanı sıra vücut yağı ve kas gücü gibi yöntemlerin de kullanılmasının ve alanında uzman diyetisyenler tarafindan beslenme bilgi düzeylerinin arttırılmasının hastalık semptomları ve yaşam kalitesi üzerinde olumlu etkiler doğurabileceği sonucuna varılmıştır.

Çalışmanın en önemli kısıtlılığı, erkek örneklemin yetersizliğinden kaynaklı kadın hastalar üzerinden değerlendirme yapılmasıdır. Vücut kompozisyonu ve besin tüketimindeki farklılıklar göz önüne alındığında, konunun ayrıntılı değerlendirilebilmesi amacı ile erkek örneklemin de dâhil edilebileceği ileri dönem çalışmalara ihtiyaç bulunmaktadır.

Çıkar çatışması - Conflict of interest: Yazarlar çıkar çatışması olmadığını beyan ederler. - The authors declare that they have no conflict of interest.

\section{KAYNAKLAR}

1. Marcora S, Lemmey AB, Maddison PJ. Dietary treatment of rheumatoid cachexia with beta-hydroxy-betamethylbutyrate, glutamine and arginine: a randomised controlled trial. Clin Nutr. 2005;24(3):442-54.

2. Gómez-Vaquero C, Nolla JM, Fiter J, Ramon JM, Concustell $\mathrm{R}$, Valverde J, et al. Nutritional status in rheumatoid arthritis. Joint Bone Spine. 2001;68(5):403-9.

3. Stavropoulos-Kalinoglou A, Metsios GS, Koutedakis Y, Nevill AM, Douglas KM, Jamurtas A, et al. Redefining overweight and obesity in rheumatoid arthritis patients. Ann Rheum Dis. 2007;66(10):1316-21.

4. Walsmith J, Roubenoff R. Cachexia in rheumatoid arthritis. Int J Cardiol. 2002;85(1):89 -99.

5. Beslenme Bilgi Sistemi (BeBİS), Bilgisayar Yazllım Programı Versiyon 7. 2007: Stuttgart, Germany.

6. National Institutes of Health (NIH). Nutrient recommendations: dietary reference intakes (DRI). Available at: https://ods.od.nih.gov/Health_Information/ Dietary_Reference_Intakes. aspx. Accessed December 3, 2018.

7. Pekcan P, Beslenme durumunun saptanması. Baysal A, Aksoy M, Besler T, Bozkurt N, Keçecioğlu S, Kutluay Merdol T ve ark, editörler, Diyet El Kitabı. 11. Baskı. Ankara: Hatiboğlu Yayınlarl; 2011. s. 67-142.

8. Küçükdeveci AA, Sahin H, Ataman S, Griffiths B, Tennant A. Issues in cross cultural validity: example from the adaptation, reliability and validity testing of a Turkish version of the Standford Health Assessment Questionnaire. Arthritis Rheum. 2004;51(1):14-9.

9. Kaya T, Karatepe AG, Günaydın R, Türkmen G,Özbek G. Romatoid artritli hastalarda yaşam kalitesi: Hastalık aktivitesi, fonksiyonel durum ve sağlık durumu ile ilişkisi. Romatizma/Rheumatism. 2007;22:119-22.

10. Eymen UE. SPSS 15.0 Veri Analiz Yöntemleri [Internet]. İstatistik Merkezi; 2007 [cited 2012 Nov 2].142 p. Available from: http://yunus.hacettepe.edu.tr/ tonta/ courses/spring2009/bby606/SPSS_15.0_ile_Veri_Analizi. pdf

11. Alvarez-Nemegyei J, Buenfil-Relloy FA, Pacheco-Pantoja EL. Association between body composition and disease activity in rheumatoid arthritis. A systematic review. Reumatol Clin. 2016;12(4):190-5.

12. Targońska-Stępniak B, Majdan M. Associations between parameters of nutritional status and disease activity in patients with rheumatoid arthritis. Pol Arch Med Wewn [Internet].2011[cited 2012 Nov 2];121(4):1228. Available from: https://pdfs.semanticscholar. org/4eb2/4f5bfe92f8f667dff6f6a3529e2a6be68ac5.pdf

13. Pekcan G, Beslenme Durumunun Saptanması. T.C. Sağllk Bakanlığı Temel Sağlık Hizmetleri Genel Müdürlüğü Beslenme ve Fiziksel Aktiviteler Daire Başkanlığı, Klasmat Matbaacılık, Ankara, 2008; s.3-50.

14. Khoja SS, Moore CG, Goodpaster BH, Delitto A, Piva SR. Skeletal muscle fat and its association with physical function in rheumatoid arthritis. Arthritis Care Res (Hoboken). 2018;70(3):333-42.

15. Elkan AC, Engvall IL, Cederholm T, Hafström I. Rheumatoid cachexia, central obesity and malnutrition 
in patients with low-active rheumatoid arthritis: feasibility of anthropometry, Mini Nutritional Assessment and body composition techniques. Eur J Nutr. 2009;48(5):315-22.

16. Plasqui G. The role of physical activity in rheumatoid arthritis. Physiol Behav. 2008;94:270-5.

17. Huffman KM, Jessee R, Andonian B, Davis BN, Narowski $\mathrm{R}$, Huebner JL, et al. Molecular alterations in skeletal muscle in rheumatoid arthritis are related to disease activity, physical inactivity, and disability. Arthritis Res Ther. 2017;19(1):1-17.

18. Cooney JK, Law RJ, Matschke V, Lemmey AB, Moore JP, Ahmad Y, et al. Benefits of exercise in rheumatoid arthritis. Benefits of exercise in rheumatoid arthritis. J Aging Res. 2011;2011:1-14.

19. Winkvist A, Bärebring L, Gjertsson I, Ellegård L, Lindqvist HM. A randomized controlled cross-over trial investigating the effect of anti-inflammatory diet on disease activity and quality of life in rheumatoid arthritis: the anti-inflammatory Diet In Rheumatoid Arthritis (ADIRA) study protocol. Nutr J. 2018;17(1):1-8.

20. Mcdougall J, Bruce B, Spiller G, Westerdahl J, Mcdougall M. Effects of a Very Low-Fat, Vegan Diet in Subjects with Rheumatoid Arthritis. J Altern Complement Med. 2002;8(1):71-5.

21. Stamp LK, James MJ, Cleland LG. Diet and Rheumatoid Arthritis: A review of the literature. Semin Arthritis Rheum. 2005;35(2):77-94.

22. Roubenoff R, Roubenoff RA, Ward LM, Stevens MB. Catabolic effects of high-dose corticosteroids persist despite therapeutic benefit in rheumatoid arthritis. Am J Clin Nutr 1990;52(6):1113-7.

23. Santos-Moreno P, Alvis-Zakzuk NJ, Villarreal-Peralta L,
Carrasquilla-Sotomayor M, Paternina-Caicedo A, AlvisGuzmán N. A comprehensive care program achieves high remission rates in rheumatoid arthritis in a middleincome setting. Experience of a Center of Excellence in Colombia. Rheumatol Int. 2017;38(3):499-505.

24. Berube LT, Kiely M, Yazici Y, Woolf K. Diet quality of individuals with rheumatoid arthritis using the Healthy Eating Index (HEI)-2010. Nutr Health. 2017;23(1):17-24

25. Hansen GVO, Nielsen L, Kluger E, Thysen M, Emmertsen $\mathrm{H}$, Stengaard-Pedersen $\mathrm{K}$, et al. Nutritional status of Danish rheumatoid arthritis patients and effects of a diet adjusted in energy intake, fish-meal, and antioxidants. Scand J Rheumatol. 1996;25(5):325-33.

26. Morgan SL, Anderson AM, Hood SM, Matthews PA, Lee JY, Alarcón GS. Nutrient İntake patterns, body mass Index, and vitamin levels in patients with rheumatoid arthritis Arthritis Care Res. 1997;10(1):9-17.

27. Bozbulut R, İşgüzar Y, Akbulut G. Romatolojik ve Kemik-Eklem Hastalıklarında Tıbbi Beslenme Tedavisi. Akbulut G, editor, Tıbbi Beslenme Tedavisinde Güncel Uygulamalar-VI 2. Baskı. Ankara: Ankara Nobel Tıp Kitabevleri; 2016. 184 s.

28. Chiplonkar SA, Agte VV, Mengale SS. Relative importance of micronutrient deficiencies in iron deficiency anemia. Nutrition Research. 2003;23(10):1355-67.

29. Aida S. Alkaline phosphatase isoenzyme activities in rheumatoid arthritis: hepatobiliary enzyme dissociation and relation to disease activity. Ann Rheum Dis. 1993;52(7):511-6.

30. Gualtierotti R, Ughi N, Marfia G, Ingegnoli F. Practical management of cardiovascular comorbidities in rheumatoid arthritis. Rheumatology and Therapy. 2017;4(2):293-308. 